\title{
Are Innovative Cooperatives More Financially Sustainable? Evidence from Primary Agricultural Credit Societies in Kerala, India.
}

\author{
Devi Sekhar $\mathrm{R}^{1}$, Sony Vijayan ${ }^{2}$ \\ \{rdevisekhar@gmail.com ${ }^{1}$, sonyvineeth@gmail.com ${ }^{2}$ \}
}

\begin{abstract}
${ }^{1}$ Research Scholar, Department of Commerce and Management, Amrita Vishwa Vidyapeetham (Deemed to be University), Kochi, India. ${ }^{2}$ Associate Professor, Department of Commerce and Management, Amrita Vishwa Vidyapeetham (Deemed to be University), Kochi, India.
\end{abstract}

\begin{abstract}
In India, the financial cooperatives, especially Primary Agricultural Credit Societies (PACS) play a major role in bringing rural and low-income population to the formal banking system. But among 95,238 PACS, only 68\% are financially viable and attaining financial sustainability remains to be a major challenge. Kerala is a state with more than $60 \%$ of its total population as members in PACS and possesses a relatively better cooperative credit system in comparison to other states. The cooperative movement in India is more than 100 years old and during this period the economy has undergone drastic changes. In this context, this paper intends to find out whether innovative cooperatives are more financially sustainable. The empirical analysis shows that only $10 \%$ of the cooperatives are financially sustainable among the selected samples. From the cases discussed, it is observed that the cooperatives which collaborate innovation with their social objectives are more sustainable.
\end{abstract}

Keywords: Financial Sustainability, Innovation, Primary Agricultural Credit Cooperatives.

\section{Introduction}

In India, agricultural credit cooperatives are highly significant as $70 \%$ of its population have dependence on agriculture and allied activities for their livelihood, either directly or indirectly. These credit cooperatives, especially Primary Agricultural Credit Societies (PACS) are playing a major role in bringing rural and low-income population to the formal banking system. They have minimized the exploitation of private money lenders and ensured adequate credit supply in rural India. There are 95238 PACS, that cover around 90\% of the villages in India with 130 million people as members [1]. But now most of these credit cooperatives are under the threat of liquidation due to various issues like high level of overdues, bad debts, mis management, improper internal control system, lack of digital banking facilities etc. According to National Federation of State Cooperative Banks Ltd (Nafscob)[1], only 68\% of PACS in India are viable as on $31^{\text {st }}$ March 2018. The Figure [1] indicates that after a steady growth in the number of PACS during 2008-10 the curve got flattened for the last 6 years. Even though new cooperatives are getting registered the curve is flattened owing to the failure and liquidation of many cooperative credit societies. A similar flattening of the curve can be observed in Figure [2] that shows the growth in the number of members in PACS. 


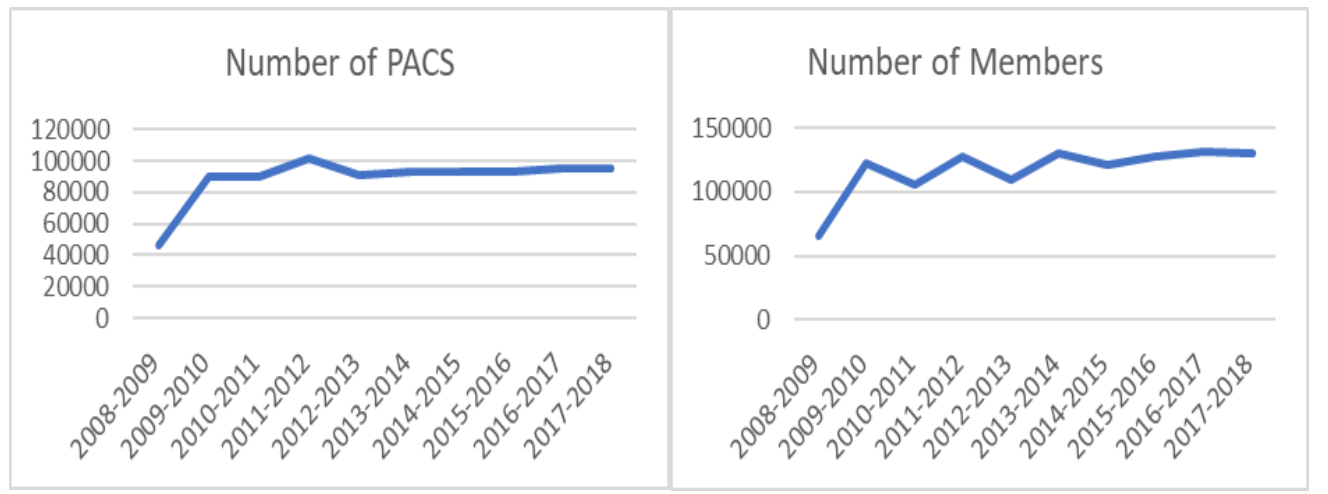

Fig. 1. Growth of PACS in India

Fig. 1. Growth in memberships of PACS in India

Kerala is a state in India with more than $60 \%$ of its total population as members in PACS. When compared to the other states, the cooperative movement in Kerala is more penetrated and successful. Apart from the banking functions they play a major role in promoting agricultural operations including marketing of produce and are actively involved in the socio-economic development of their entire area of operation by promoting subsidized medical stores, stationary stores, computer centres, health care centres, educational institutions etc. When the state had got affected by floods in 2018 and 2019 the PACS had actively participated in the 'Care Home' Project of the state Government to build houses for the flood affected families. Now during the Covid 19 Pandemic, apart from the donations made to the Government's relief funds, they extended interest free loans to their members. In Kerala as on March 2018, there are 1647 PACS among which 1462 are active (Table.1). Kerala has a better cooperative credit structure and its policies and practices get adopted in many other parts of the country. The three-tier rural short-term credit structure (State Cooperative Bank - District Cooperative Bank - PACS) in Kerala has been transformed into a two-tier structure by merging the first and second tiers to form the Kerala cooperative Bank in 2019. The newly formed Kerala Cooperative Bank has PACS as its members and at least for the initial years the bank has to be highly dependent on PACS for deposits and advances [2].

Table 1: Statistics on PACS

\begin{tabular}{|l|l|l|l|l|l|l|}
\hline & PACS No. & Viable & $\begin{array}{l}\text { Potentially } \\
\text { Viable }\end{array}$ & Dormant & Defunct & Others \\
\hline India & 95,238 & 64,382 & 17,965 & 2,709 & 1,542 & 8,640 \\
\hline Kerala & 1,647 & 1,462 & 136 & 33 & 10 & 6 \\
\hline
\end{tabular}

\subsection{Sustainability}

Attaining financial sustainability is one of the major challenges faced by credit cooperatives. Broadly, sustainability means the capacity of an organization to continue its operations for a longer period. According to Dunford (2000)[3], sustainability means covering the operational and financial cost. As per CGAP (2003)[4], the sustainability of a micro finance institution is defined as the "ability of a microfinance provider to cover all of its costs and achieving financial sustainability means reducing transaction costs, offering better products and services that meet client needs, and finding new ways to reach the unbanked poor"

\subsection{Innovation}

Today, innovation has become very vital for each and every business enterprise. According to Edquist (1997)[5] innovations can increase productivity and material welfare but at the same time it will destroy 
old jobs and create new employment opportunities. In literature, various perspectives on innovation can be found. Rosenberg, 1982 [6] defined innovation as any process that enhance the existing technology. According to Pavitt, 1984 [7], innovation is a process that turns opportunities to commercial uses. E. M. Rogers \& Shoemaker, 1971 [8] has put forward a broader perspective on innovation and defined it as any new technology or new process or both. The paper considers this perspective because cooperatives are small organizations working mostly in rural areas managed by common people and not by professionals. Therefore, adoption of any new technology or process in their functioning are of high value. The theories on innovation cannot establish a common framework for estimating and analysing innovation because the perspective of innovation is firm specific. It also depends on the industry, the firm belongs to and the socioeconomic environment in which the firm operates [9]. As far as primary cooperatives are considered, they do not have a specific Research and Development department nor a budget for innovation. Hence, we are initiating a case study approach to find out whether the most sustainable firms are implementing any new process or technology into their banking operations.

\section{Literature Review}

Nyamsogoro, 2010 [10] found that efficiency and outreach affect the financial sustainability of micro finance institutions. Marwa \& Aziakpono, 2015 [11] found that 61 percent of savings and credit cooperatives in Tanzania were operationally sustainable, while 51 percent were both operationally and financially sustainable. The study also reveals that the cooperative institutions which are lending to the poor and low-income population have higher cost of funds, poor return and involve relatively higher risk. The determinants of financial sustainability of microfinance institutions in Bangladesh were studied by Rahman \& Mazlam, 2014 [12] and revealed that size, cost per borrower, productivity and yield have a positive relationship with sustainability while number of borrowers, age of the firm and debt equity ratio have a negative impact on sustainability. Duguma \& Han, 2018 [13] conducted a study among Ethiopian credit cooperatives and found that interest rate spread has a negative impact on sustainability while deposit to loan ratio, deposit to total assets ratio and the volume of deposits have a positive impact on sustainability.

According to world bank (2010)[14], innovations in agricultural and rural finance will improve the livelihoods of the poor and ensure sustainable access to credit. Innovative programs like linking of SelfHelp Groups (SHGs) to banks had great impact on financially empowering rural women and households [15]. Morduch [16] in his paper titled as 'The Microfinance Promise' commented that, "the promise of microfinance was founded on innovation: new management structures, new contracts and new attitudes". According to Dutz, 2007 [17] India with $65 \%$ of its total population (1.35 billion) below 35 years, is underperforming in terms of its innovation potential. Hence India has to improve on its innovation potential to ensure sustainability in economic growth.

[18] Popat, 2016 has analysed the performance of PACS along the period 2006-07 to 2010-11. The tools used are Compound Annual Growth Rate (CAGR) and graphical comparison. The study revealed a negative growth rate in the number of PACS and membership of PACS in India. But paid up capital has a growth rate of $9 \%$. The loans issued during the period showed growth rate at $20.09 \%$ (CAGR) and loan outstanding by $18.63 \%$. The overall growth rate of PACS during the period are found to be at a slow but an increasing pace. According to Saravanadurai et. al. (2016)[19], PACS can be considered as the pillars of cooperative credit system in the country and the rural population has a higher dependency on them for agricultural credit.

\section{Methodology}

From the literatures reviewed we identify a paucity on the studies that measures sustainability of primary credit cooperatives in India and also could not identify any literatures that emphasise the innovation in credit cooperatives. There we observe a research gap. The cooperative movement was started as a very innovative tool for eradicating poverty and empowering rural population by ensuring ample credit supply. 
In India the movement is more than 100 years old and during this period the economy has undergone drastic changes. Commercial banks and regional rural banks have started operating in rural areas and created highly competitive market environment for the poor. In 1999, Jonathan Morduch [16] has called for a 'second major wave of innovation' in microfinance institutions by encouraging more experimentation and proper evaluation. Similarly, primary credit cooperatives also have to adopt innovative policies and procedures to overcome their problems and challenges. In this context, we are addressing the following research questions; (1) to what extent the Primary Agricultural Credit Cooperatives in Kerala are financially sustainable (2) are innovative cooperatives more financially sustainable.

The paper has two parts, first part measures the financial sustainability of a sample of cooperatives and the second part involves a case study approach to understand whether the most sustainable cooperatives have implemented any innovative practices in their banking business. The sample size comprises 60 PACS that are randomly collected from three districts in Kerala. Kollam from South region, Ernakulam from Central region and Kozhikode from North region. Each cooperative has been visited and conducted discussions with the employees. Also collected their annual reports and brochures.

\section{Analysis \& Discussion}

CGAP(2013) proposed a measurement formula for financial sustainability. Nyamsogoro, 2010 and Marwa \& Aziakpono, 2015 [10] and [11] had employed this equation for measuring financial sustainability of rural micro finance institutions and credit cooperatives in Tanzania. Thus, according to CGAP Consultative Group to Assist the Poor (2003), Financial Self-sufficiency (FSS) can be measured as;

$$
\mathrm{FSS}=\frac{\text { Adjusted Operating Revenue }}{(\text { Financial Expense }+ \text { Loan loss provision expense +operating expense+Expense adjustment) }}
$$

a) Operating Revenue: It comprises financial revenue and all other operating income. For PACS, it is computed under interest income and other income.

b) Adjusted Operating Revenue: This is the time period inflation adjusted operating revenue and not taken into account as the paper has considered cross sectional data as on 31 $1^{\text {st }}$ March 2019 and the comparison is made between firms working under the same market conditions.

c) Operating Expenses: It includes personnel expenses and administrative expenses.

d) Financial Expenses: It is defined as the interest and fees incurred on liabilities; loans and borrowings. In PACS it is given under the accounting head, interest expenses.

e) Loan loss provisions: It is a non-cash expense created to reduce loan default risk and is a specific percentage of loans and its interest at risk. PACS have provision for bad debts and overdue interest. Thus, the formula for measuring financial sustainability of PACS is;

$$
\text { FSS of PACS }=\frac{\text { Interest Income+Other Expenses }}{\left(\begin{array}{c}
\text { (Interest Expenses }+ \text { other expenses }+ \text { provision for bad debts }+ \\
\text { Provision for overdue interest })
\end{array}\right.}
$$

The results indicate that only $10 \%$ of selected samples have achieved financial sustainability (scores $\geq 1$ ) during the financial year 2018-19 and $37 \%$ have a sustainability score between 0.75 and 1 . A mean sustainability value of 0.7012 is obtained for the sample considered. The financial sustainability scores among PACS varies widely even though all of them are working under the same set of regulations and similar market conditions. $23 \%$ of them have sustainability scores below 0.5 . The district wise comparison shows the cooperative credit societies in Kozhikode are more sustainable than Ernakulam and Kollam. Another finding is that the cooperatives in Municipal Corporations (Cities) are more sustainable than those in Panchayats (Villages) and Municipalities (Towns).

In the recent years, PACS in Kerala are being confronted by various regulatory norms in the banking and financial sector. When the higher denomination currency notes were demonetized in 2016, the Reserve Bank of India have restricted PACS from collecting demonetized notes. They are also facing issues like 
restrictions in cash transactions, income tax problems, lack of demand for agricultural loans, high volume of overdue loans, political interventions etc. Besides all these factors, the results show that $10 \%$ of PACS are financially sustainable and $37 \%$ have a score value between 0.75 and 1 . Thus we can infer that internal factors play a vital role in determining financial sustainability.

\subsection{Sustainability and Innovation}

Based on the sustainability scores cooperatives are divided into four groups (Table.2 \& Fig. 3). The innovative policies and procedures of each cooperative are identified by conducting structured interviews with the employees and Board Members.

Table. 2. Sustainability Scores

\begin{tabular}{|llll|}
\hline Groups & $\begin{array}{l}\text { Sustainability } \\
\text { Score }\end{array}$ & $\begin{array}{l}\text { No. of Credit } \\
\text { Cooperatives }\end{array}$ & Percentage \\
Group 1 & $1 \&$ above & 6 & $10 \%$ \\
Group 2 & 0.75 to 1 & 22 & $37 \%$ \\
Group 3 & 0.5 to 0.75 & 18 & $30 \%$ \\
Group 4 & Below 0.5 & 14 & $23 \%$ \\
\hline
\end{tabular}

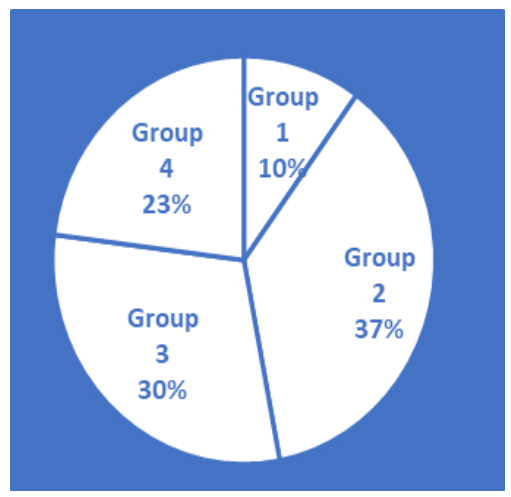

\subsection{Innovation in Group 1 Cooperatives}

Fig. 3. Classification of Cooperatives

Digitalization: The cooperatives in this group are found to give more importance to digitalization and most of them provide various digital banking facilities to their members. As far as cooperatives are considered this is an innovative procedure because even now there exist PACS which are not even computerised.

Extension of banking hours: Most the cooperatives in this group are extending banking hours for the convenience of working class. This is through setting up morning or evening branches or extending banking facilities to even 12 hours. The managers commented that this would help the daily wagers by not losing their pay for doing banking transactions. This would enable other working-class members also visit the cooperatives after their office hours.

Specialised Products: All the cooperatives in this group are providing specialised loans with low interest to women, small businessmen, shopkeepers etc. They also promote their products by setting up separate counter for gold loans, senior citizens etc. Two of the cooperatives from this group is providing special savings schemes for school kids.

Promotion of Organic farming: A cooperative has been found to be promoting organic farming among members through the sale of high-quality seeds from Agricultural University and helps in the sale of organic vegetables.

\subsection{Innovation in Group 2 Cooperatives}

Social Innovation: Cooperatives in this group are found to be more socially innovative and most of their programs are in initial stages, therefore they have higher chances of getting financial sustainability in the coming years. Along with their own self-sufficiency they are working for the development of their entire area of operation. 
Working along with Self-help Groups: Most of the cooperatives in this group are getting involved with various self-help groups for promoting agriculture and self-employment. Some of the cooperatives have created small groups for farmers and started cultivating the barren lands.

Getting involved in all stages of agricultural production process: Rather than credit supply the cooperative will extend their help towards all the stages of agricultural production by providing all inputs, collection and storage of produce and finally set up shops for selling the produce.

\subsection{Innovation in Group III and Group IV Cooperatives}

From these groups we could identify only a few innovative practices like providing ambulance services, drinking water supply during summer season, setting up markets during festivals and sale of organic fertilizers. The cooperatives are autonomous institutions but the State Government get involved in its activities to prevent fraudulent transactions and protecting the investors' funds. The board and the management of the cooperative have to make all the strategic planning and get the approval from the Department of Cooperation, Government of Kerala. But most of the cooperatives in this group believe they have to just work as per the instructions from the Government. They are not making any strategic planning or initiatives internally. As a result, their overdues are scaling up and have to keep high amount as provisions.

\section{Summary}

The empirical analysis shows that only $10 \%$ of the cooperatives are financially sustainable among the selected sample. The cases discussed in this paper shows, the cooperatives which collaborate innovation with their social objectives are more sustainable. This is because every primary agricultural credit cooperative has a specified area of operation beyond which they cannot do banking business. This could be a village, town, city or a part of it. Thus, the cooperative should focus on a sustainable development of the entire area of operation which includes the upliftment of the poor and underprivileged population, creating employment opportunities through agriculture and allied activities, enhancing social development by setting up schools, hospitals, health care centres etc and creating awareness among their members on cooperative model. The financial sustainability is highly relevant for any institutions to continue its behaviour for a longer time [20].

The study reveals that through innovation, cooperatives can address most of their difficulties. The cooperatives can achieve financial sustainability by developing their area of operations and getting actively involved in social development. In 1999, Morduch [16] has called for a 'second major wave of innovation' in microfinance institutions by encouraging more experimentation and proper evaluation. Similarly, the cooperative movement in India also need a transformation through innovation. The cooperative movement is still relevant to the Indian economy because it has not addressed the issues like high income disparity, less development in rural areas, majority of population engaged in agriculture, higher rate of unemployment, lack of adequate credit to farmers and resulting farmers' suicides.

\section{Limitations and Suggestions for Further Research}

As no prior studies were conducted in this area, the study used a case study approach to analyse the innovative practices in PACS. For case studies, large sample size is not practical and hence considered only 60 cooperatives. Now further research can be conducted using quantitative methods to establish the relationship between innovation and sustainability. The cooperative model can also help the huge young unemployment population to set up self-employment units. Thus, more researches should be conducted in this area to exploit the benefits of cooperative models for a sustainable social development. 


\section{References}

[1] Nafscob, "Performance of Primary Agricultural Credit Societies," Nafscob, 2019.

http://nafscob.org/pacs_f.htm.

[2] Sreeram M S, "Expert Committee on the Formation of Kerala Co-operative Bank Final Report," 2017. Accessed: Jul. 06, 2020. [Online]. Available:

https://kerala.gov.in/documents/10180/9a3e118f-791c-46c7-9451-f51913681e00.

[3] C. Dunford, "In Search of 'Sound Practices' for Microfinance," J. Microfinance / ESR Rev., vol. 2, no. 1, Apr. 2000, Accessed: Jul. 06, 2020. [Online]. Available:

https://scholarsarchive.byu.edu/esr/vol2/iss1/2.

[4] Cgap, "Microfinance Consensus Guidelines: Definitions of Selected Financial Terms, Ratios, and Adjustments for Microfinance," 2003. Accessed: Jul. 06, 2020. [Online]. Available: www.seepnetwork.org.

[5] Edquist Charles, Sysetems of Innovation, 2nd ed. London: Taylor \& Francis, 1997.

[6] N. Rosenberg, Inside the Black Box: Technology and Economics . New York: Cambridge University Press, 1982.

[7] K. Pavitt, "Sectoral patterns of technical change: Towards a taxonomy and a theory," Res. Policy, vol. 13, no. 6, pp. 343-373, Dec. 1984, doi: 10.1016/0048-7333(84)90018-0.

[8] E. M. Rogers and F. . Shoemaker, Communication of Innovations: A cross cultural approach. New York: The Free Press.

[9] V. Souitaris, "Technological trajectories as moderators of firm-level determinants of innovation," Res. Policy, vol. 31, no. 6, pp. 877-898, 2002.

[10] G. D. Nyamsogoro, "Financial Sustainability of Rural Microfinance Institutions ( MFIs ) in Tanzania," Int. J. Bank Mark., vol. 5, no. September, p. pp.130-210, 2010.

[11] N. Marwa and M. Aziakpono, "Financial sustainability of Tanzanian saving and credit cooperatives,” Int. J. Soc. Econ., vol. 42, no. 10, pp. 870-887, Oct. 2015, doi: 10.1108/IJSE-062014-0127.

[12] M. A. Rahman and A. R. Mazlan, "Determinants of Financial Sustainability of Microfinance Institutions in Bangladesh," Int. J. Econ. Financ., vol. 6, no. 9, Aug. 2014, doi: 10.5539/ijef.v6n9p107.

[13] G. Duguma and J. Han, "Effect of Deposit Mobilization on the Financial Sustainability of Rural Saving and Credit Cooperatives: Evidence from Ethiopia," Sustainability, vol. 10, no. 10, p. 3387, Sep. 2018, doi: 10.3390/su10103387.

[14] R. Kloeppinger and M. Sharma, Innovations in Rural and Agriculture Finance. 2009.

[15] "NABARD - National Bank For Agriculture And Rural Development." https://www.nabard.org/content.aspx?id=651 (accessed Jul. 06, 2020).

[16] J. Morduch, “The microfinance promise," J. Econ. Lit., vol. 37, no. 4, pp. 1569-1614, 1999, doi: 10.1257/jel.37.4.1569.

[17] M. Dutz, Unleashing India's Innovation. The World Bank, 2007.

[18] M. Popat, "Growth \& Performance of Primary Agricultural Cooperative," no. October 2013, pp. $0-9,2016$.

[19] A. Saravanadurai and N. Manimehalai, "Primary agricultural credit societies in India ," Int. Res. J. Eng. IT Sci. Res., vol. 2, no. 7, Jul. 2016, Accessed: Jul. 06, 2020. [Online]. Available: https://sloap.org/journals/index.php/irjeis/article/view/498\#pkp_content_nav.

[20] B. Rogers, "Credit Union Sustainability:Costs, Consolidation,and Differentiation," 2011. https://p.widencdn.net/t1lkcd/251_EXS_Berkeley_Sustainability (accessed Jul. 09, 2020). 